\title{
Structure of the Crust Beneath the South Western Cameroon, from Gravity Data Analysis
}

\author{
Marcel Jean 1,2, E. J. M. Abate ${ }^{3,4}$, P. Njandjock Nouck ${ }^{1}$, H. E. Ngatchou1, V. Oyoa ${ }^{1,5}$, \\ C. T. Tabod ${ }^{1,6}$, E. Manguelle-Dicoum ${ }^{1}$ \\ ${ }^{1}$ Department of Physics, Faculty of Science, University of Yaounde I, Yaounde, Cameroon \\ ${ }^{2}$ National Institute of Cartography, Ministry of Scientific Research and Innovation, Yaounde, Cameroon \\ ${ }^{3}$ Geological and Mining Research Institute, Ministry of Scientific Research and Innovation, Yaounde, Cameroon \\ ${ }^{4}$ Department of Earth Science, Faculty of Science, University of Yaounde I, Yaounde, Cameroon \\ ${ }^{5}$ Department of Physics, Advance Teacher's Training College, University of Maroua, Maroua, Cameroon \\ ${ }^{6}$ Department of Physics, Faculty of Science, University of Bamenda, Bambili, Cameroon \\ Email: *pnnouck@yahoo.com
}

Received 7 May 2016; accepted 12 August 2016; published 15 August 2016

Copyright (C) 2016 by authors and Scientific Research Publishing Inc.

This work is licensed under the Creative Commons Attribution International License (CC BY).

http://creativecommons.org/licenses/by/4.0/

c) (i) Open Access

\section{Abstract}

The study area is located in the south western Cameroon and includes part of the Cameroon Volcanic Line (CVL). Volcanic activity has been recorded in this area, precisely on the Mount Cameroon which recently erupted in 2002 . In addition, deadly carbonic gas was emitted by crater lakes (Monoun and Nyos) in 1984 and 1986 respectively. Potential field model EGM2008 has been used to investigate the structure of the crust. A regional/residual separation is performed using upward continuation and polynomial separation methods. The results from this operation show a similarity between the regional anomalies resulting from both methods. The regional anomaly maps present an increasing gradient trending ENE-WSW above and below latitude $5^{\circ} \mathrm{N}$. Moreover, six nearly parallel profiles were drawn on the CVL in addition to two other profiles at the northern edge of Congo craton. These profiles were used to estimate the depths of the Moho discontinuity and some shallow sources by the means of the Bouguer and the residual anomalies respectively. The results show that the Moho discontinuity depths vary from 19 - $25 \mathrm{~km}$ (under Mount Cameroon) to 28 - $34 \mathrm{~km}$ (in Kumbo), while the southern neighbouring zone presents a Moho discontinuity depth ranging between $23-31 \mathrm{~km}$ (in Ngambe) and $22-32 \mathrm{~km}$ (in Eseka). These findings agree with the previous seismic and gravity researches lead in the area. EGM2008 is therefore a reliable tool to investigate the subsurface structures.

\footnotetext{
*Corresponding author.
}

How to cite this paper: Jean, M., Abate, E.J.M., Nouck, P.N., Ngatchou, H.E., Oyoa, V., Tabod, C.T. and Manguelle-Dicoum, E. (2016) Structure of the Crust Beneath the South Western Cameroon, from Gravity Data Analysis. International Journal of Geosciences, 7, 991-1008. http://dx.doi.org/10.4236/ijg.2016.78075 


\section{Keywords}

\section{South Western Cameroon, EGM2008, Bouguer Anomaly, Spectral Analysis, Moho Discontinuity}

\section{Introduction}

Gravity survey over Cameroon and its adjacent countries (Central African Republic, Chad and Nigeria) consists of local surveys collected in the 1960s and 1980s [1] [2]. The existing database shows a very good distribution in some specific areas like the Chad sedimentary basin because of petroleum investigation interest; unfortunately, other zones such as mountains, forests and those lake road infrastructures are less covered, making it difficult for the scientific studies. The part of the CVL belonging to the study area is covered by thick forest associated to highlands, with few carriageable roads. Hence, the available terrestrial gravity data distribution is highly uneven. Nevertheless, many important geophysical investigations based on terrestrial gravity data have been carried out along CVL, and important scientific results have been obtained by [3]-[7]. However, new generations of global models of gravity field such as EGM2008 ([8]) have the highest available spatial resolution in addition to their ability to provide precise and uniform gravity data. Moreover, they are freely available. Their compilation keeps the promise to overcome the sparseness of data, and can provide more information on the structure of the subsurface.

In this work, we use EGM2008 to reinforce the possibilities of applying this potential field model in regional mapping. Such works have previously been conducted by [9]-[13]. This proves its efficiency.

The present task aims to determine the structure of the crust beneath the study area through regional/residual separation of Bouguer anomalies. Residual anomalies are produced by shallow sources while regional anomalies are due to deeper ones. Therefore, this separation can enable us to estimate the depth to major discontinuities with an emphasis on the Moho discontinuity, as a contribution to the study of the subsurface along the CVL. The determination of the Moho discontinuity depth is very important for it firstly gives an insight about the isostatic compensation of the area and secondly; it shows the contribution of both shallow and deep seated features of the Bouguer anomalies. Several geophysical techniques have been used for the same purpose along the CVL, but the EGM2008 data provide better resolution than the ones used in the previous studies. This study also evaluates the efficiency of EGM2008 and its accuracy in recognising major tectonic and structural elements.

\section{Geological Setting}

The study area (Figure 1) includes part of the CVL and the northern edge of the Congo craton. The CVL belongs to the Pan-African Fold Belt, between the West African and the Congo cratons. It is made of volcanoes that trend $\mathrm{N} 30^{\circ} \mathrm{E}$ and extends from the Island of Pagalù in the gulf of Guinea to Lake Chad [14]: thus, the CVL is formed by an oceanic and a continental parts. It is underlain by Pan African basement rocks consisting mainly of schists and gneisses intruded by granites and diorites [14]-[16]. Cretaceous sediments, mostly sandstones and small amounts of limestone and shales are found in the coastal plain. Volcanic rocks that comprise the CVL range in composition from basalts to trachytes. For example, Mt. Manengouba (2420 m) consists of basalt, trachyte and rhyolite lavas, Mt. Cameroon (4095 m), the largest of the continental volcanoes, is mainly formed by alkaline basalts [17] and Mt. Etinde (1713 m), one of the older volcanoes, is made of nephelinitic lavas [18]. Other examples include Mt. Bamboutos (2670 m), which is characterized by the presence of alkali basalts and trachytes, and Mt. Oku (3011 m) where transitional basalt, quartz trachyte and rhyolite flows are found [19].

Previous deep-imaging multifold seismic shooting in the offshore part of the CVL, from [20], shows asymmetric uplift of the Moho discontinuity (thinning of the oceanic crust) which is associated with extensive magmatism, occuring near some main volcanic centres. [19] discovered that basalts from both oceanic and continental sectors are geochemically and isotopically indistinguishable, implying a similar mantle source. The geochemical and isotopic similarities between the CVL oceanic and continental basalts attest that the continental crust did not play any role in the magma genesis and that the source is not of lithospheric origin [16]. Along the CVL, mantle-derived (ultramafic) xenoliths have been found in several locations in basaltic lavas [14] [16] [21]. Despite the similarities in geochemical composition of volcanic lavas, no evidence has been found for a consistent migration of volcanic activity with time beneath the CVL. 


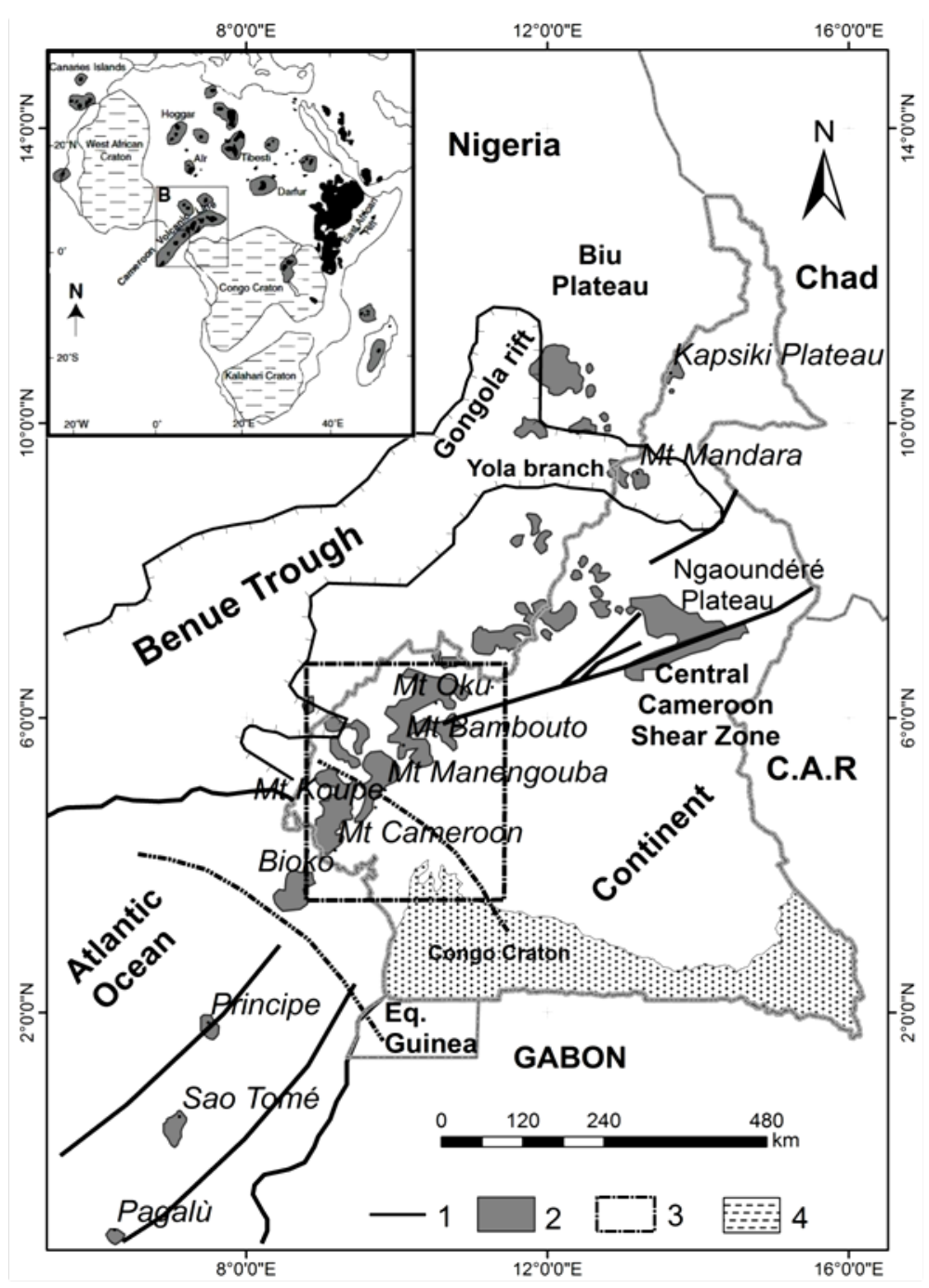

Figure 1. Location of the study area, modified from [32]. (1) Fault; (2) CVL;

(3) Pan-African Fold Belt; (4) Congo craton.

Figure 2 represents the geological map of the study area, a compilation from [22]-[27]. This map shows two main geological domains, namely: the northern edge of the Congo craton, which is, according to [28], a set dominated by plutonic formations of the TTG suite (tonalites-trondhjemites-granodiorites); and the Pan-African Belt of Central Africa, marked by formations of the CVL.

The whole study area is subject of many geological events, such as the deadly magmatic gas releases in Lake Monoun (1984) and Lake Nyos (1986) [29], the volcanic eruptions of Mt. Cameroon which last erupted in the year 2000 ([30]), and also many seismic events which regularly recorded in the area. However, more in formations collected from the Cameroonian ministry in charge of mining affairs [31] indicate the presence of many mineral indices in the study area. Thus, all the previous findings show the importance of carrying more geophysical investigations in the area, for both scientific and socioeconomic (i.e.: civil protection, mineral resource prospection) purposes.

\section{Data and Method}

\subsection{Data}

Two different gravity databases are available for the study area: the terrestrial and the earth gravitational model EGM2008. 


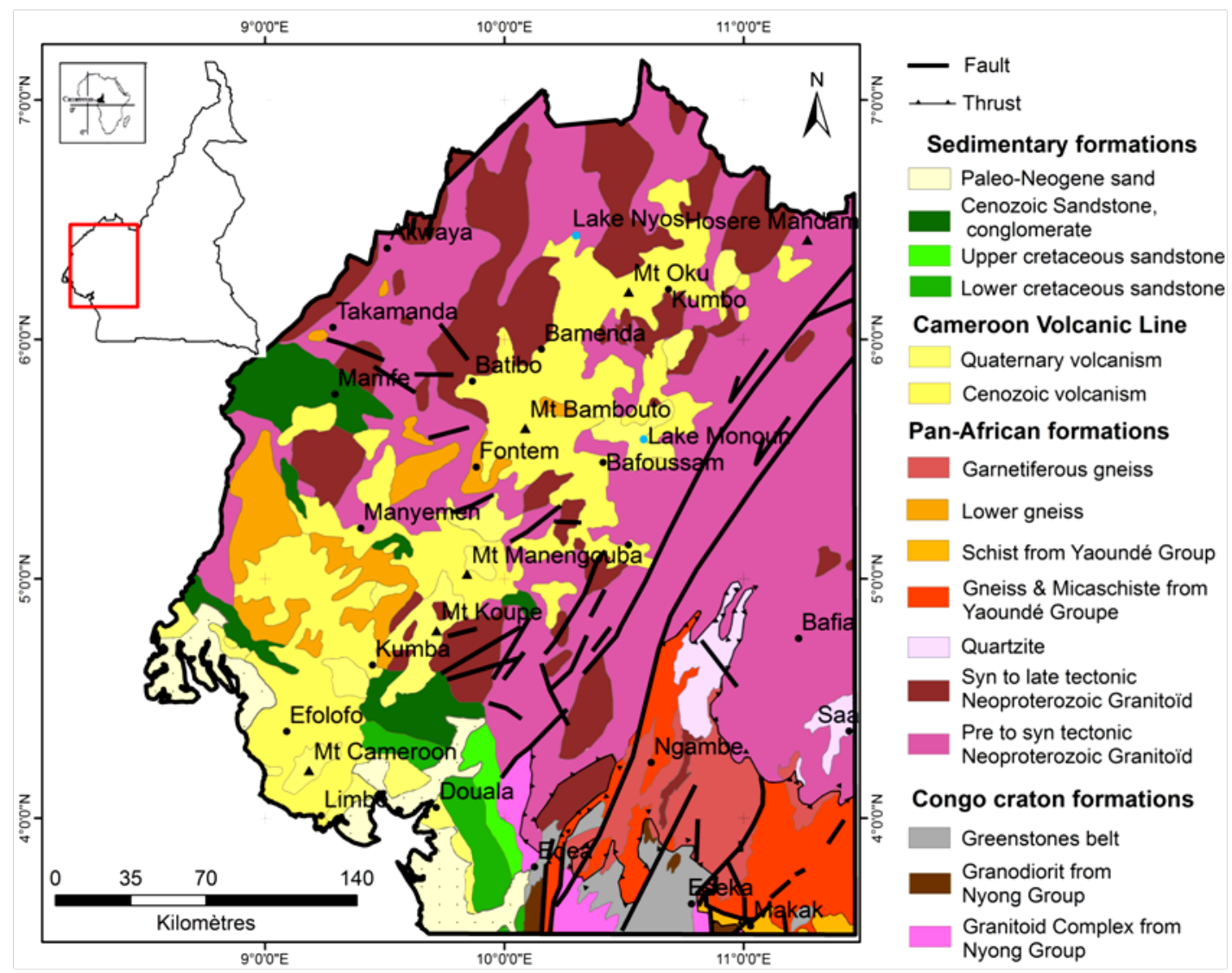

Figure 2. Geological map of the study area, compiled from [22]-[27].

\subsubsection{The Terrestrial Data}

The land gravity data available in the study area consist of about 670 observation points. The uneven distribution of measurements constitutes an unreliable basis of gravity analysis.

Figure 3 shows that the region of Kumbo including the localities of Bamenda and Bafoussam is characterized by negative Bouguer anomalies of high amplitude (down to $-110 \mathrm{mGal}$ ), while in the Mount Cameroon, the values are positive (up to $100 \mathrm{mGal}$ ). Data are not available in the Ngambe, Fontem and Takamanda areas, which makes it diffucult the proper gravity investigations. Therefore, these data must undergo other processings such as an interpolation technique in order to fill the gaps.

\subsubsection{The Earth Gravitational Model: EGM2008}

The second database derives from the Earth Gravitational Model 2008 [8] [33]. The EGM2008 has been publicly released by the National Geospatial-Intelligence Agency (NGA) EGM Development Team of The United States of America. The data are first obtained as Free-Air Gravity Anomalies (Figure 4). The WGS 84 Geodetic Reference System (GRS) was used to define the geometry and the normal gravitational potential of the reference ellipsoid. The computed values refer to the surface of this reference ellipsoid. This gravitational model is complete to spherical harmonic degree and order 2159, and contains additional coefficients extending to degree 2190 and order 2159. The EGM2008 Bouguer anomalies are obtained after applying the topographic correction using the ETOPO 1 Digital Elevation Model [34], presented in Figure 5, and crust density contrast reduction of 2670 $\mathrm{kg} / \mathrm{m}^{3}$.

The EGM2008 presents a complete high resolution database, composed of previous land, marine, and airborne gravity data, and gravity anomalies from satellite observation. It therefore comprises data from inaccessible areas, contributing to overcome the problem of low resolution data.

Figure 6 shows values that spread from -255 to $198 \mathrm{mGal}$. This potential field signal has a deep correlation with former geological surveys in this area. In fact, around some volcanic mountains (Bafoussam, Bamenda, 


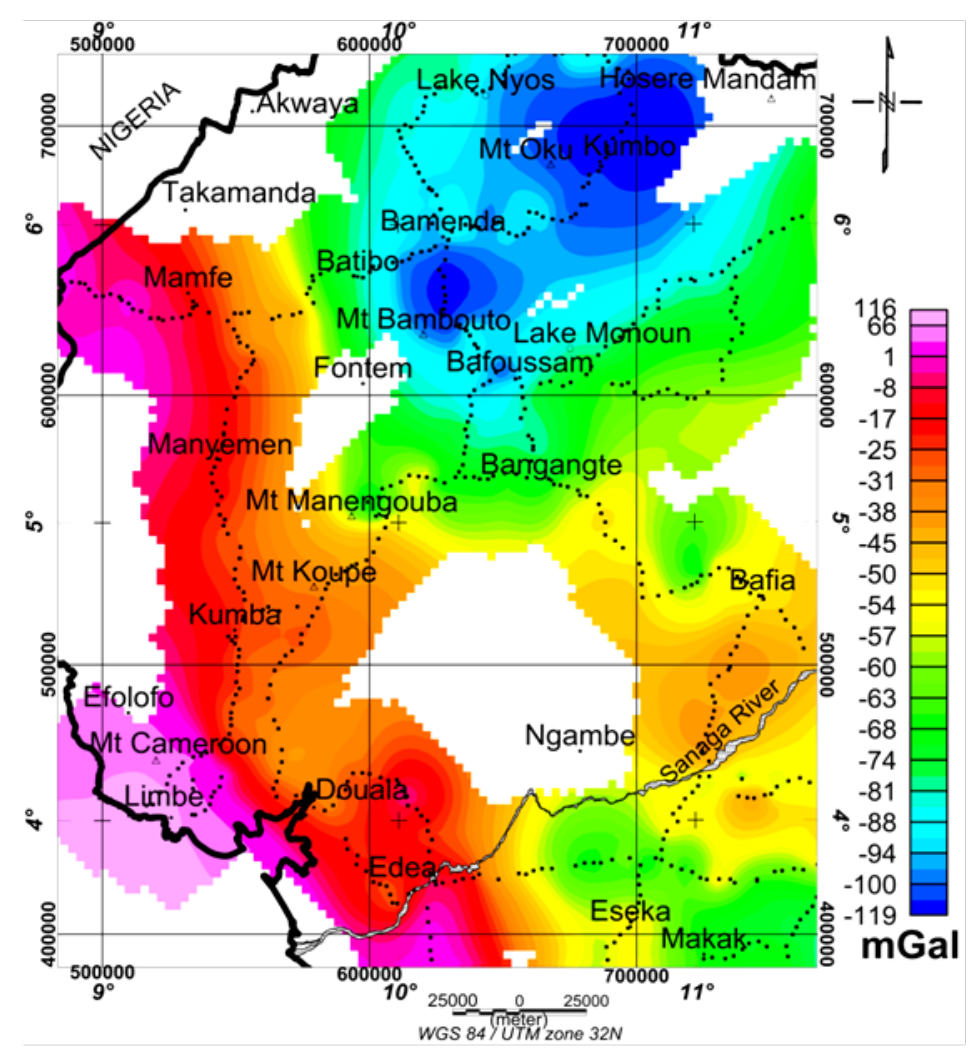

Figure 3. Bouguer anomaly map from existing land gravity data.

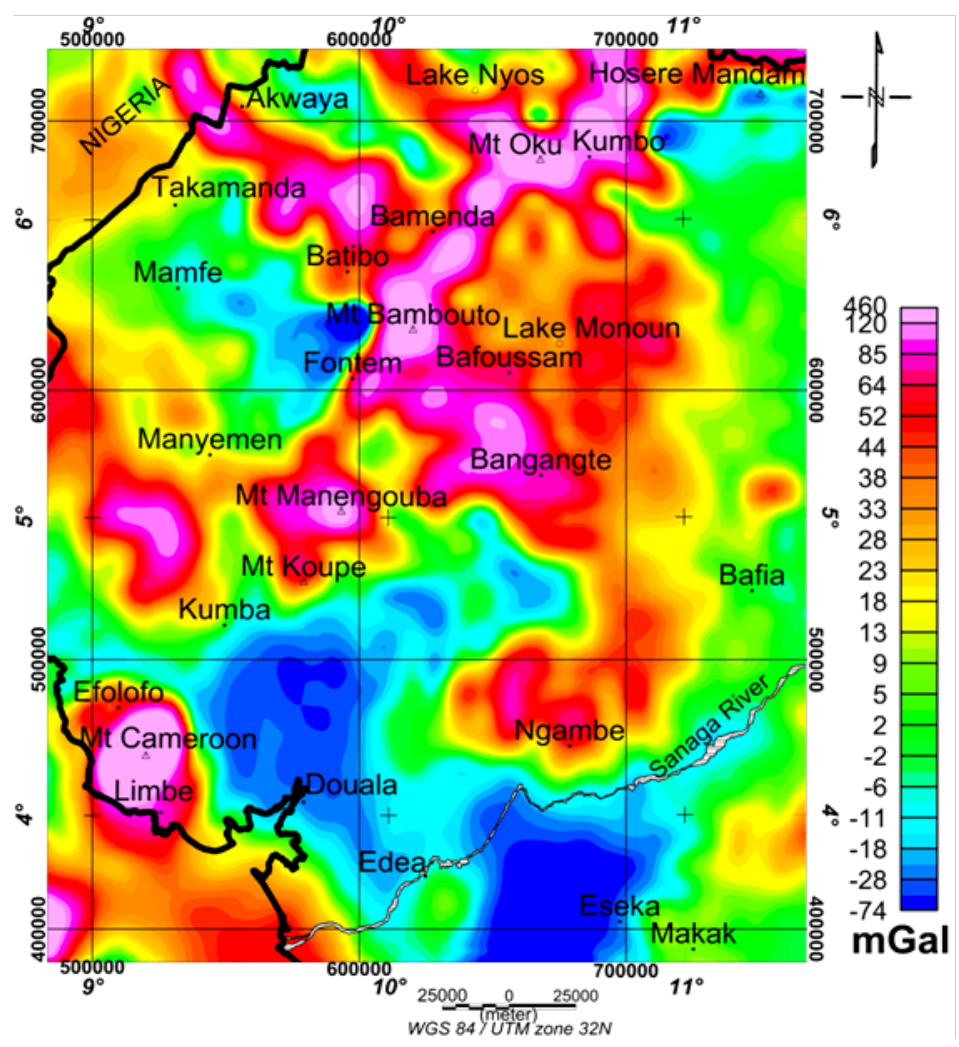

Figure 4. Free air anomaly map of the study area derived from EGM2008. 


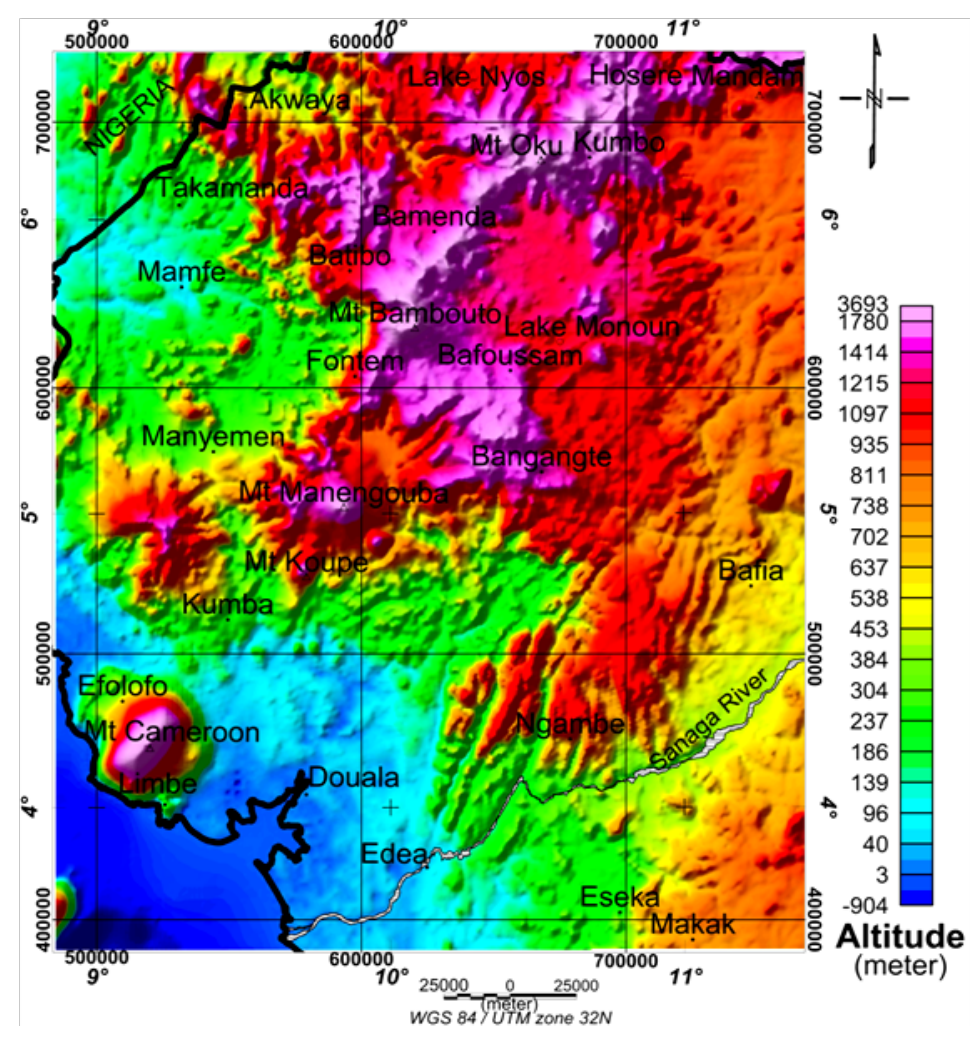

Figure 5. ETOPO 1 digital elevation model of the study area.

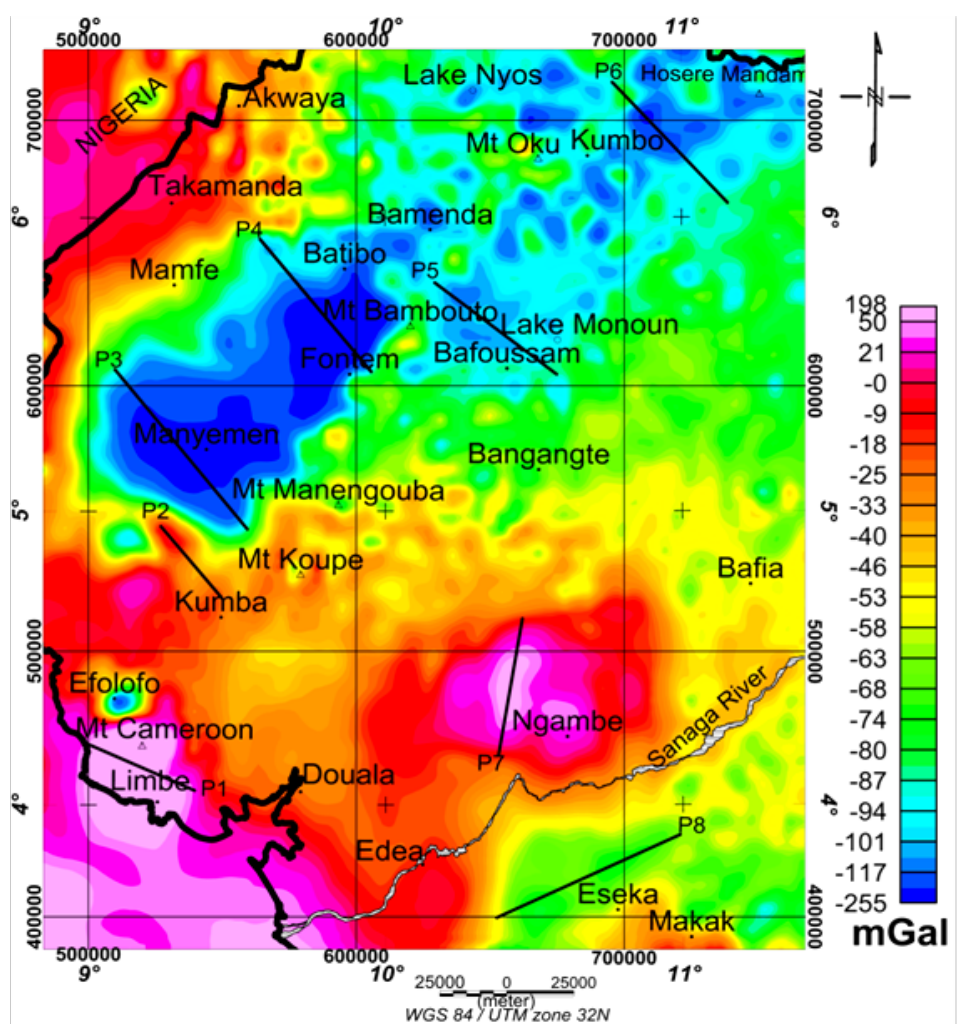

Figure 6. Bouguer anomaly map of the study area derived from EGM2008, dashed lines are profiles. 
Mt Oku, until Hossere Mandam), there is a sequence of located negative anomalies that follow $\mathrm{N} 30^{\circ} \mathrm{E}$ trend. In the Mamfé basin, EGM2008 Bouguer anomaly indicates around the Manyemen and Fontem localities, an ellipsoid-shaped feature characterized by negative anomalies that extend from -255 to $-90 \mathrm{mGal}$. This sedimentary basin is characterized by the lowest Bouguer anomaly values of the study area. Yet, Mt Cameroon which is the only active volcano of the CVL appears under a positive anomaly with values above $190 \mathrm{mGal}$, at the boundary ocean-continent. The oceanic zone presents positive anomalies ranging from 20 to $190 \mathrm{mGal}$. The North of Mt Cameroon is characterized by a very located negative anomaly that can be considered as a minor basin. Around Sanaga River, there are two circular positive anomalies: in Ngambe area it reaches 90 mGal whereas below Edea it is medium with $10 \mathrm{mGal}$ average. The South-East of the map ends with a half circular anomaly around Eseka-Makak. The Lakes Monoun and Nyos that produced deadly gas in 1984 and 1986 respectively coincide with localized negative Bouguer anomalies. Globally, apart from the Mt Cameroon region characterized by positive Bouguer anomalies, all other mountains are located in zones of negative Bouguer anomalies.

\subsection{Method}

The Bouguer gravity anomalies are the sum of contributions from both superficial and deeper structures, corresponding respectively to the residual and regional anomalies [35]. According to [36], an optimal regional anomaly exists, and represents the contribution of the Moho discontinuity to the total Bouguer anomaly for an area. Based on this assumption, the depth of major discontinuities beneath the study area can be easily estimated. It consists of 1) the determination of the optimal regional anomaly map amenable for the study area, and 2) the depth estimation of the Moho discontinuity and some shallow located discontinuities using the spectral analysis technique.

\subsubsection{Method of Determining the Optimal Regional Anomaly}

The determination of the optimum regional anomaly map for the study area lies on the method of [37]. This method consists of two different stages:

The first stage is to determine a suitable altitude for the application of the upward continuation technique in the study area [38] [39]. The upward continuation technique is applied to the Bouguer anomalies at several altitudes $\left(h_{i}\right)$, with the same sample point $\Delta h\left(h_{2}=h_{1}+\Delta h\right)$. The extrema of each altitude of upward continuation are then counted. These are points where the gradient is null [40]. Further, a graph of extrema versus altitudes of upward continuation is plotted. Finally, the suitable altitude $\left(H_{o p}\right)$ necessary for the upward continuation technique is determined graphically. The authors show that for any other altitude $h>H_{o p}$, the number of extrema is approximately constant. In this case, the upward continued anomaly maps are similar in form and design of isogals, and only the amplitudes of the anomalies differ.

The second stage is the determination of the optimal degree for the regional anomaly. [37] proposed a calculation technique summarized by the following expressions and formula:

Let us fit polynomials $p_{d}\left(x_{i}, y_{i}\right)$ given by the expression

$$
\begin{aligned}
& f\left(x_{i}, y_{i}\right)=a_{0}+a_{1} x_{i}+a_{2} y_{i}+\cdots+a_{k} y_{i}^{n} \\
& p_{d}\left(x_{i}, y_{i}\right)=b_{0}+b_{1} x_{i}+b_{2} y_{i}+\cdots+b_{k} y_{i}^{d}
\end{aligned}
$$

where $k=\frac{(d+1)(d+2)}{2}-1 ; \quad d=1,2, \cdots, n-1, n-2, \cdots 1 ; i=1,2, \cdots, M$.

$n$ is maximal degree of fitting and $M$ is the number of data points according to the principle of minimum variance $\sigma_{d}$. Therefore, the variance $\sigma_{d}$ is calculated through the following expression:

$$
\sigma_{d}=\frac{1}{M} \sum_{i}^{M}\left[f\left(x_{i}, y_{i}\right)-p_{d}\left(x_{i}, y_{i}\right)\right]^{2}
$$

This technique is applied to the Bouguer anomalies for the $H_{o p}$ altitude. The $H_{o p}$ upward continued anomaly is fitted by polynomials of various degrees ( 1 to 12 ) with the analytic least-square method [41]-[46], and the variance of the data obtained for each degree is calculated [37]. Finally, the optimum degree of the polynomial evaluating this anomaly can be estimated from the point of discontinuity on a graph of variance against the degree of the polynomial. 
To obtain the optimum regional anomaly of the study area, the Bouguer anomaly observed is fitted by a polynomial of the optimum degree determined previously, with the analytic least-squares method. Consequently, there must be some similarities between the optimum regional anomaly and the $H_{o p}$ upward continued maps.

\subsubsection{Depth Determination from Spectral Analysis}

Spectral analysis has been widely used by several authors to estimate the depth of various structures from gravity and magnetic data [7] [13] [47]-[55]. This analysis provides a quantitative technique for the study of large and complex aeromagnetic or gravity dataset. The logarithm of radial average of the energy spectrum (i.e. the square of the Fourier amplitude spectrum) is plotted versus the frequency. The slope of each segment provides information about the depth to the top of an ensemble of magnetic or gravity bodies [56]. This method does not require an a priori knowledge of the geometry and density contrasts of source bodies.

\section{Results and Discussion}

\subsection{The Optimal Regional Anomaly Map of the Study Area}

The third-order regional anomaly map (Figure 9) has been chosen for the present work after applying the method of [37]. Practically, the calculations made accordingly led us to plot the graph of the extrema versus the altitudes of upward continuation (Figure 7) and that of the variance against the degree of the polynomial (Figure 8).

According to [36], regional anomaly presents the contribution of the Moho discontinuity to the total Bouguer anomaly. Thus, it reflects the undulations of the Moho beneath the study area. The third-order regional anomaly map (Figure 9) and $30 \mathrm{~km}$ upward continuation (Figure 10) are similar. It confirms the reliability of the method proposed by [37]. For an easier interpretation, the study area has been divided into two main domains:

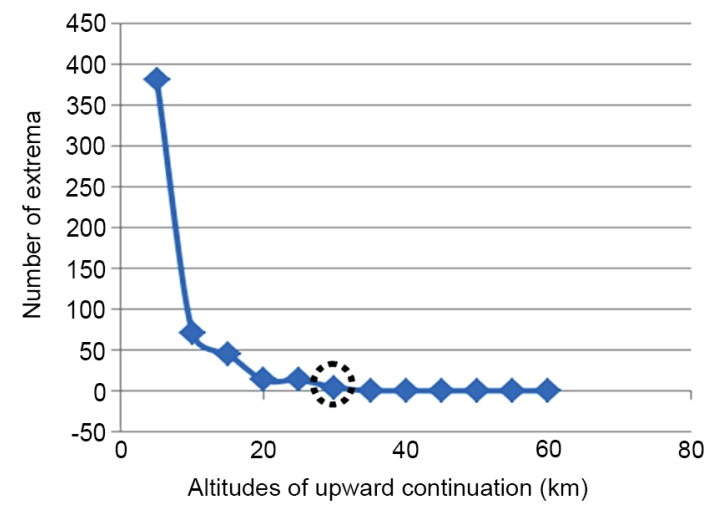

Figure 7. Graph of number of extrema point against upward continuation height.

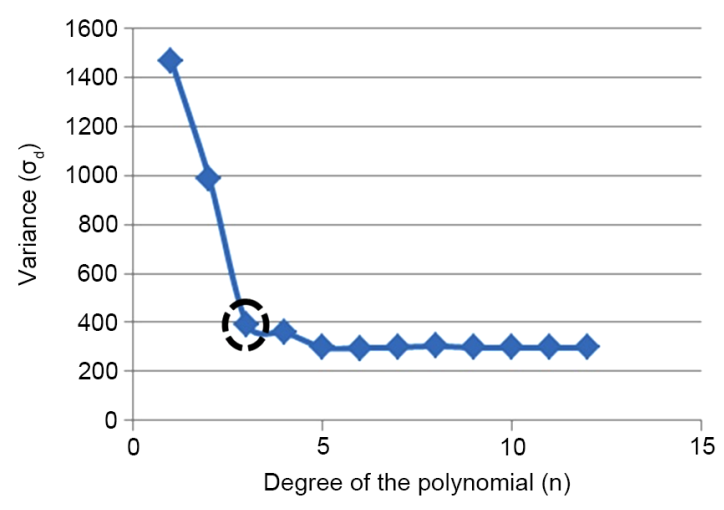

Figure 8. Graph of variance against degree of the polynomial. 


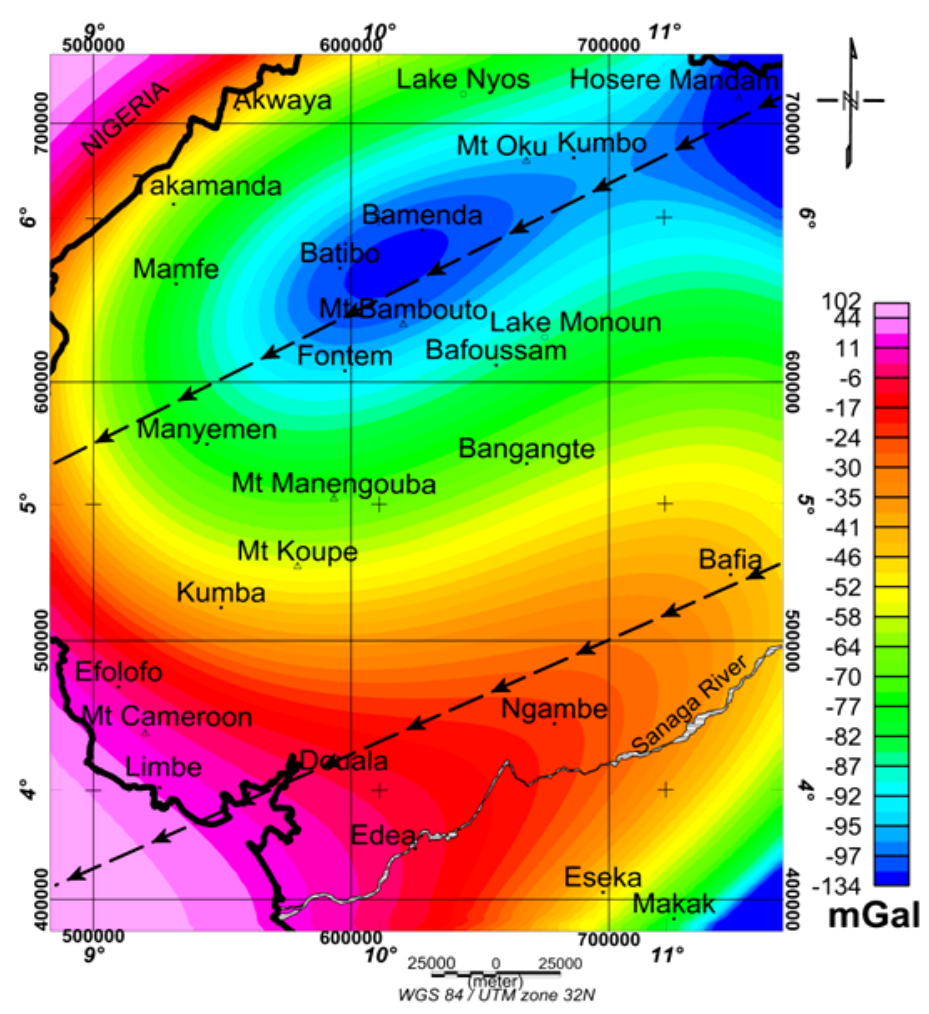

Figure 9. Third-order regional anomaly map from EGM2008, arrows representing the orientation of gradient.

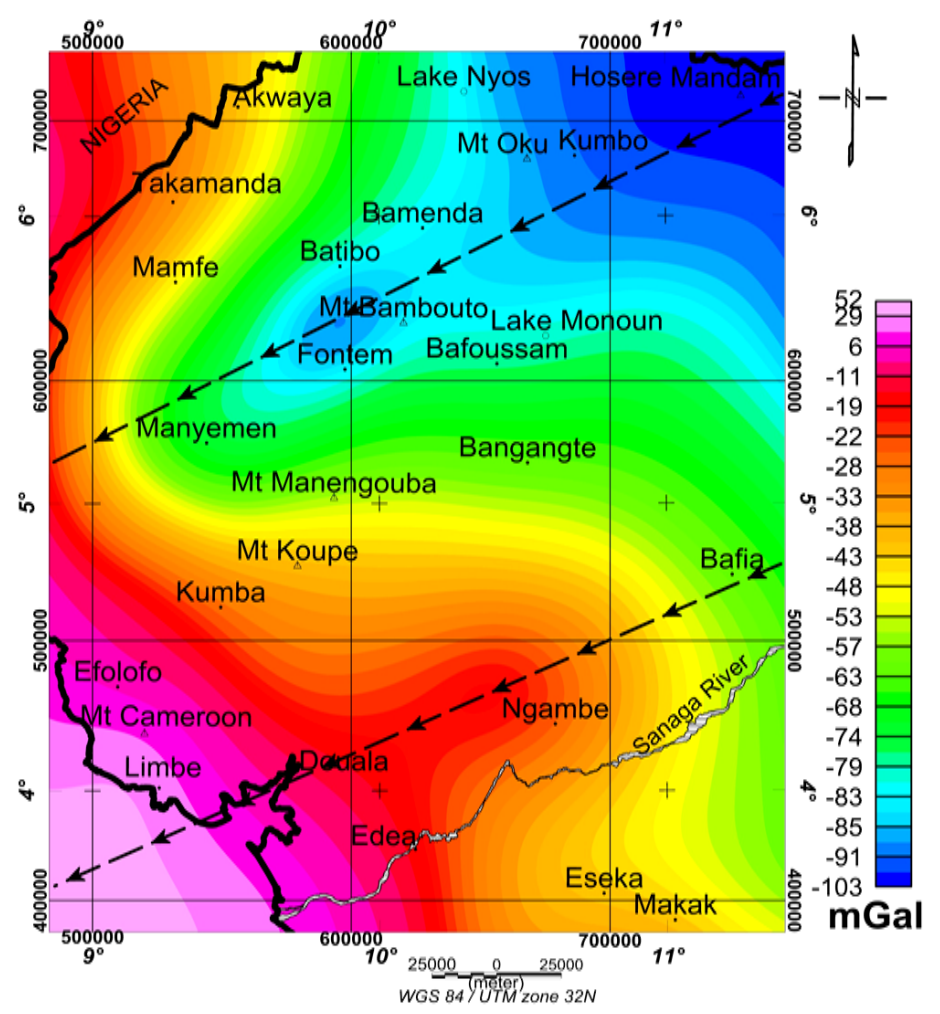

Figure 10. $30 \mathrm{~km}$ upward continued regional anomaly map from EGM2008, arrows representing the orientation of gradient. 
- The first one is located above latitude $5^{\circ} \mathrm{N}$, characterized by negative regional anomalies orientated WSWENE. These anomalies extend from Manyemen in the Mamfé basin to the north-east of Kumbo mountainous region where the minimum of anomalies reaches approximately—130 mGal. It emerges on this field a strong gradient orientated in the NE-SW direction, suggesting an uplift of the Moho discontinuity in the Mamfé area and a thickening of the crust in the one of Kumbo;

- The second domain is located below latitude $5^{\circ} \mathrm{N}$. It shows positive regional anomaly in the Mount Cameroon region. The magnitude of the regional anomaly decreases from WSW to ENE. This domain is heavier than the first one in terms of the magnitudes of the observed regional anomaly, and also reveals a strong gradient orientated ENE-WSW. From this, it can be assumed that the Moho is uplifted in the Mount Cameroon region than in the Ngambe one.

In general, the qualitative interpretation of the regional anomaly leads to predict a thin crust in the Mount Cameroon region and thickened one in Kumbo and its surrounding areas.

Figure 7 and Figure 8 represent the diagrams of extrema versus altitudes of upward continuation and variance against the degree of the polynomial respectively. They show the values of $30 \mathrm{~km}$ used for the upward continuation technique and 3 as the degree of the polynomial. These values are represented by dashed-circles.

\subsection{The Residual Anomaly Map}

The choice of the third-order regional anomaly for the present work influences that of the residual anomaly. Therefore, the third-order residual anomaly is obtained after subtracting the third-order regional anomaly from the total Bouguer anomaly. The third-order residual anomaly (Figure 11) has some similarities with that of Bouguer anomaly; this because the trend of positive and negative anomalies is still maintained. Nevertheless, above latitude $5^{\circ} \mathrm{N}$, the residual anomaly map shows the presence of many intrusions of dense materials along the CVL, and precisely in the areas of Bafoussam, Bamenda, Kumbo, etc. The study area may have been object of many mineralization processes that can predict economic potentialities [31], making the whole region interesting for both scientific and economic purposes.

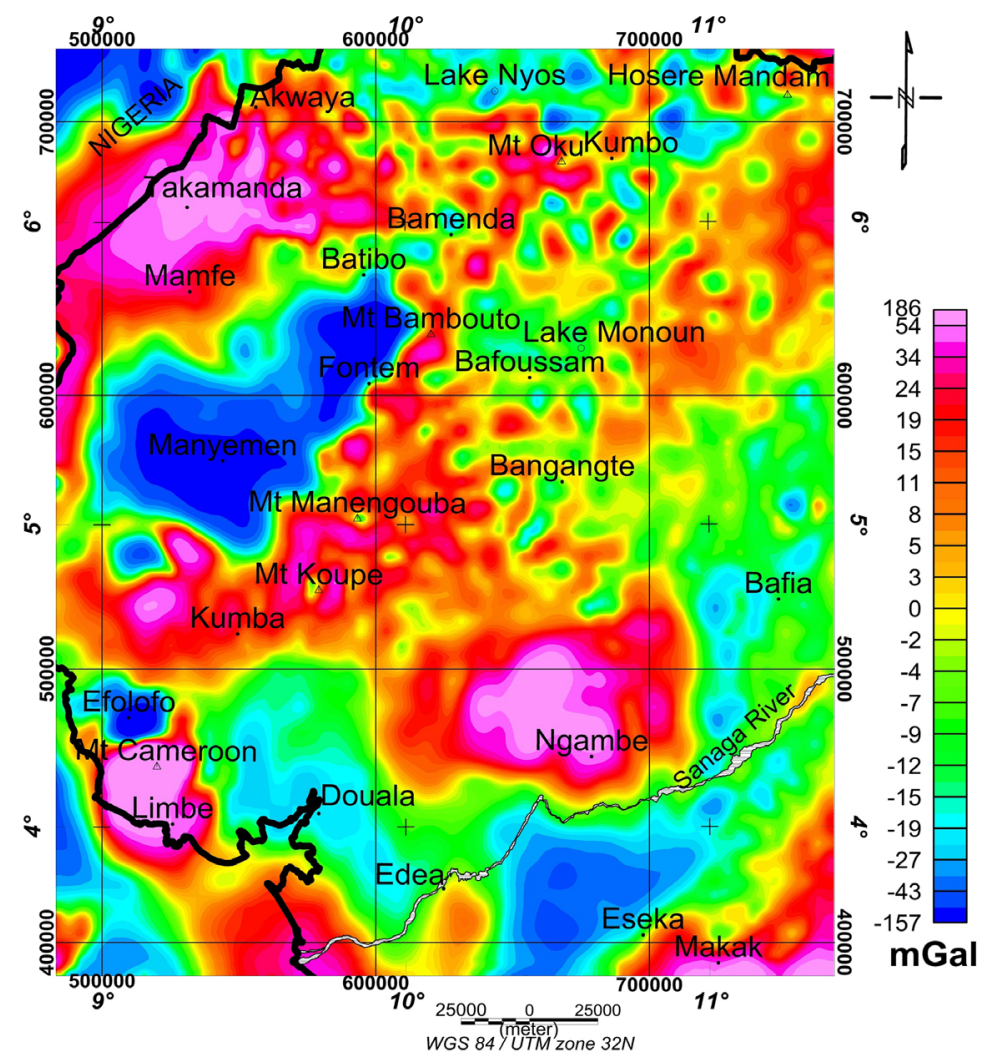

Figure 11. Third-order residual anomaly map from EGM2008. 


\subsection{Depth Estimation of Major Discontinuities}

Table 1 presents the synthesis of the significant dense and less dense structures in the study area, from which we chose eight and drew profiles on the Bouguer anomalies map (Figure 6) for the depth calculations. Figure 12 to Figure 19 and Table 2 and Table 3 summarise all the results. They give in one hand the depth estimation of Moho discontinuity and on other hand the depth of some shallow structures.

\subsubsection{Estimation of the Moho Discontinuity Depth}

The present work shows that neither the positive Bouguer anomalies nor the negative ones are associated with a thickening of the crust:

- The Moho discontinuity beneath the Mt Cameroon is estimated around (22 \pm 3$) \mathrm{km}$. The previous studies conducted in the same region led to the following detphs: 19 to $21 \mathrm{~km}$ obtained by [5] using gravity data; 22 to $26 \mathrm{~km}$ by [7] from gravity data. [57] analysed seismic data and proposed a crustal depth of about $25.5 \mathrm{~km}$;

- In the Kumbo area, the crustal depth is evaluated at $(31 \pm 3) \mathrm{km}$. [1] used gravity data to estimate the Moho depth in the same area to about 30 - $34 \mathrm{~km}$. Seismic investigations conducted by [58] led to a depth estimate of approximately $33 \mathrm{~km}$, whereas [7] used also the gravity data and got a depth between 29 and $33 \mathrm{~km}$, compared to approximately $33 \mathrm{~km}$ from [57];

- In the Mamfe region, the thickness of the crust is about (27 \pm 3$) \mathrm{km}$ in the locality of Manyemen and (29 \pm 4$)$ $\mathrm{km}$ around Fontem. These results agree well with the findings of [57] giving an estimation of about 31 in the same area;

- In Kumba graben, we got a depth of (22 \pm 4$) \mathrm{km}$. which result is not far from $28 \mathrm{~km}$ obtained by [57] from seismic analysis;

- In Ngambe and Eseka regions located at the transitional zone between the Congo craton and the Pan-African belt, we estimated a Moho depth of about (27 \pm 4$)$ and (27 \pm 5$)$ km respectively, while [59] found a depth of about 25 - $29 \mathrm{~km}$ in the same area.

The results obtained in this work (Table 2) highlight a fundamental fact: a general thinning of the crust (uplift of the Moho) along the CVL. For example, the results show that the positive Bouguer anomalies of high magnitude observed in the Mt. Cameroon region are associated to a thin crust, while in the Kumbo region where the

Table 1. Synthetic table of interesting Bouguer anomalies of the study area. Anomalies associated with P, are studied deeply according to the profiles dawn on Bouguer anomalies map.

\begin{tabular}{|c|c|c|c|}
\hline Anomalies/location & Amplitude & Direction/trend & Causes/significance \\
\hline Mount Cameroon, Limbe $\left(\mathrm{P}_{1}\right)$ & $\begin{array}{l}\text { High amplitude positive } \\
\text { anomalies }\end{array}$ & Quasi-circular & $\begin{array}{l}\text { Cenozoic to actual volcanic formation, } \\
\text { active volcano }\end{array}$ \\
\hline Ngambe $\left(\mathrm{P}_{7}\right)$ & $\begin{array}{l}\text { High amplitude positive } \\
\text { anomalies }\end{array}$ & Quasi-circular & $\begin{array}{l}\text { Transitional zone between the Congo } \\
\text { craton and the Pan-African, mantle } \\
\text { intrusion injected by Sanaga Fault }\end{array}$ \\
\hline $\begin{array}{l}\text { Takamanda, Cameroon-Nigeria } \\
\text { boundary }\end{array}$ & $\begin{array}{l}\text { High amplitude positive } \\
\text { anomalies }\end{array}$ & Quasi-circular & $\begin{array}{l}\text { Old granit and basement } \\
\text { complex formation }\end{array}$ \\
\hline Beneath Edéa & Relative positive anomalies & Quasi-circular & $\begin{array}{l}\text { Transitional zone between the Congo } \\
\text { craton and the Pan-African, mantle } \\
\text { intrusion injected by Sanaga Fault }\end{array}$ \\
\hline Eseka, Makak $\left(\mathrm{P}_{8}\right)$ & Relative negative anomalies & Located signature & Congo craton signature \\
\hline Kumba $\left(\mathrm{P}_{2}\right)$ & Negative anomalies & Located signature & Cenozoic to actual volcanic formation \\
\hline Manyemen-Fontem $\left(\mathrm{P}_{3}\right.$ and $\left.\mathrm{P}_{4}\right)$ & $\begin{array}{c}\text { High amplitude negative } \\
\text { anomalies }\end{array}$ & CVL direction $\left(\mathrm{N}^{\circ} 30 \mathrm{E}\right)$ & Sedimentary basin of Mamfe \\
\hline $\begin{array}{l}\text { Mt Bambouto-Mt Oku-Kumbo } \\
\qquad\left(\mathrm{P}_{5} \text { and } \mathrm{P}_{6}\right)\end{array}$ & $\begin{array}{l}\text { Line of successive negative } \\
\text { anomalies }\end{array}$ & $\begin{array}{l}\text { CVL line direction } \\
\left(\mathrm{N}^{\circ} 30 \mathrm{E}\right)\end{array}$ & Cenozoic to actual volcanoes from CVL \\
\hline Lakes Nyos and Monoun & Negative anomalies & Located signature & Crater lakes associated with gas emission \\
\hline $\begin{array}{l}\text { Efolofo in the North of } \\
\text { Mount Cameroon }\end{array}$ & Negative anomalies & Located signature & Minor basin \\
\hline
\end{tabular}


Table 2. Comparison of the Moho depth estimated from various studies.

\begin{tabular}{|c|c|c|c|}
\hline Anomalies/location & Amplitude & $\begin{array}{l}\text { Moho depth from the } \\
\text { present work }(\mathrm{km})\end{array}$ & $\begin{array}{l}\text { Moho depth from previous } \\
\text { investigations (km) }\end{array}$ \\
\hline \multirow{3}{*}{ Mount Cameroon, Limbe $\left(\mathrm{P}_{1}\right)$} & \multirow{3}{*}{$\begin{array}{l}\text { High amplitude positive } \\
\text { anomalies }\end{array}$} & \multirow{3}{*}{$19-25$} & $19-21[5]$ \\
\hline & & & $22-26[7]$ \\
\hline & & & $\sim 25.5[57]$ \\
\hline Kumba, $\left(\mathrm{P}_{2}\right)$ & Negative anomalies & $18-26$ & $\sim 28[57]$ \\
\hline Manyemen, $\left(\mathrm{P}_{3}\right)$ & High amplitude negative anomalies & $25-33$ & $\sim 31[57]$ \\
\hline Fontem, $\left(\mathrm{P}_{4}\right)$ & High amplitude negative anomalies & $24-30$ & $\sim 31[57]$ \\
\hline \multirow{4}{*}{$\begin{array}{c}\text { Bafoussam } \\
\text { (NE Mt Cameroon), }\left(\mathrm{P}_{5}\right)\end{array}$} & \multirow{4}{*}{$\begin{array}{c}\text { Line of successive negative } \\
\text { anomalies }\end{array}$} & \multirow{4}{*}{$21-31$} & $30-34[1]$ \\
\hline & & & $\sim 33[58]$ \\
\hline & & & $28-32[5]$ \\
\hline & & & $\sim 31[57]$ \\
\hline \multirow{5}{*}{ NE of Kumbo, $\left(\mathrm{P}_{6}\right)$} & \multirow{5}{*}{$\begin{array}{c}\text { Line of successive negative } \\
\text { anomalies }\end{array}$} & \multirow{5}{*}{$28-34$} & $30-34[1]$ \\
\hline & & & $\sim 33[58]$ \\
\hline & & & $28-32[5]$ \\
\hline & & & $29-33[7]$ \\
\hline & & & $\sim 33[57]$ \\
\hline Ngambe, $\left(\mathrm{P}_{7}\right)$ & High amplitude positive anomalies & $23-31$ & \\
\hline Eseka, Makak, $\left(\mathrm{P}_{8}\right)$ & Relatively negative anomalies & $22-32$ & 25 - 29 [59] \\
\hline
\end{tabular}

Table 3. Depth to interesting shallow structures in the study area.

\begin{tabular}{|c|c|c|c|}
\hline Anomalies/location & Amplitude & $\begin{array}{l}\text { Depth of shallow } \\
\text { structures }(\mathrm{km})\end{array}$ & $\begin{array}{l}\text { Shallow structure depth from } \\
\text { previous studies }(\mathrm{km})\end{array}$ \\
\hline Mount Cameroon, Limbe, $\left(\mathrm{P}_{1}\right)$ & High amplitude positive anomalies & $8-12$ & $7-9[5]$ \\
\hline Kumba, $\left(\mathrm{P}_{2}\right)$ & Negative anomalies & $5-9$ & \\
\hline Manyemen, $\left(\mathrm{P}_{3}\right)$ & High amplitude negative anomalies & $4-8$ & $4.5-7[13]$ \\
\hline Fontem, $\left(\mathrm{P}_{4}\right)$ & High amplitude negative anomalies & $6-8$ & $4.5-7[13]$ \\
\hline $\begin{array}{c}\text { Bafoussam, } \\
\text { (NE Mt Cameroon), }\left(\mathrm{P}_{5}\right)\end{array}$ & $\begin{array}{l}\text { Line of successive negative and } \\
\text { positive superficial anomalies }\end{array}$ & $5-9$ & \\
\hline NE of Kumbo, $\left(\mathrm{P}_{6}\right)$ & $\begin{array}{l}\text { Line of successive negative and } \\
\text { positive superficial anomalies }\end{array}$ & $3-7$ & \\
\hline Ngambe, $\left(\mathrm{P}_{7}\right)$ & High amplitude positive anomalies & $5-7$ & \\
\hline Eseka, Makak, $\left(\mathrm{P}_{8}\right)$ & Relatively negative anomalies & $6-8$ & \\
\hline
\end{tabular}




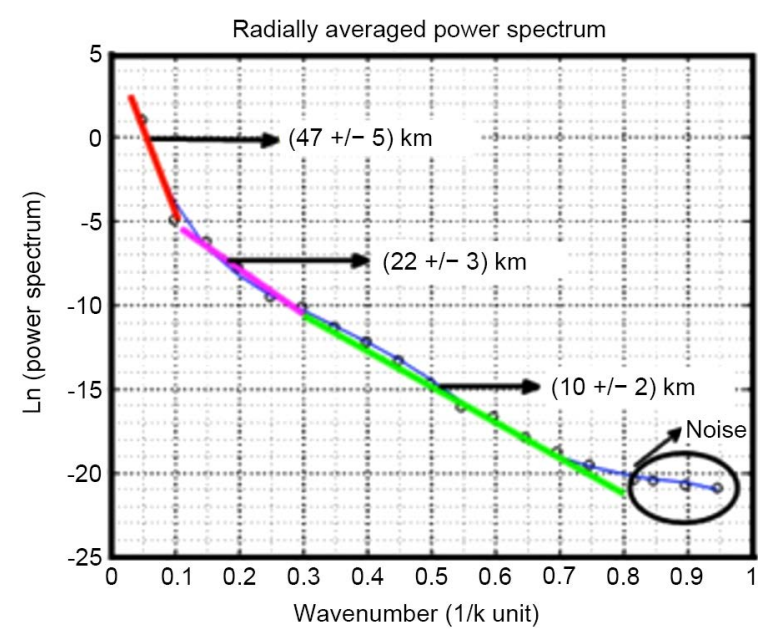

Figure 12. Power spectrum versus frequency for profile $\mathrm{P}_{1}$ (Mount Cameroon).

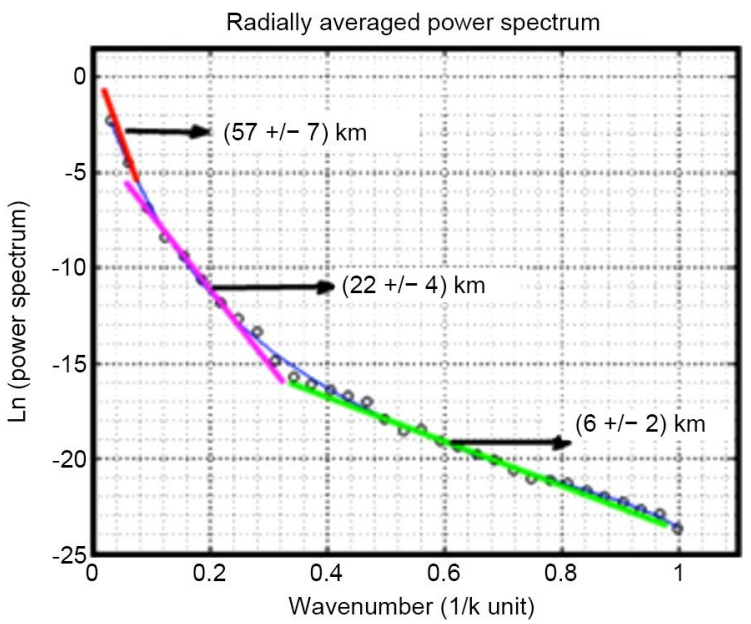

Figure 13. Power spectrum versus frequency for profile $\mathrm{P}_{2}$ (Kumba region).

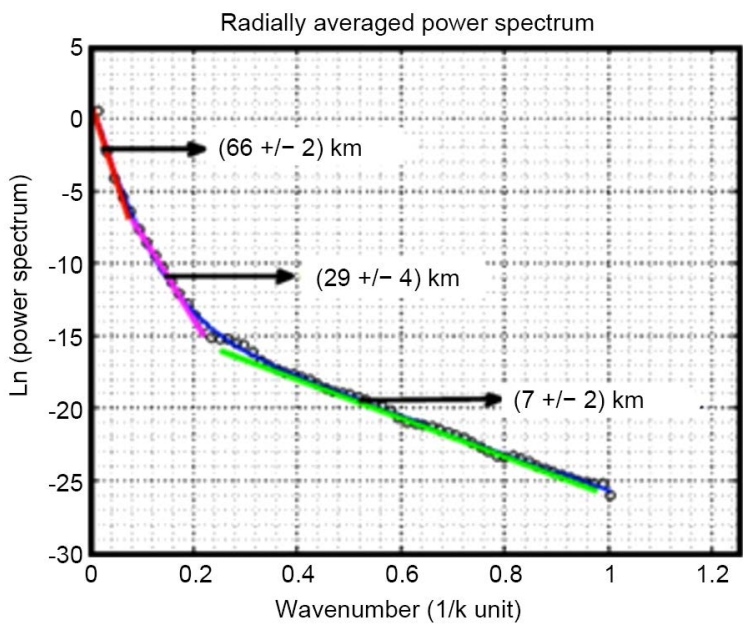

Figure 14. Power spectrum versus frequency for profile $\mathrm{P}_{3}$ (Manyemen, Mamfe region). 


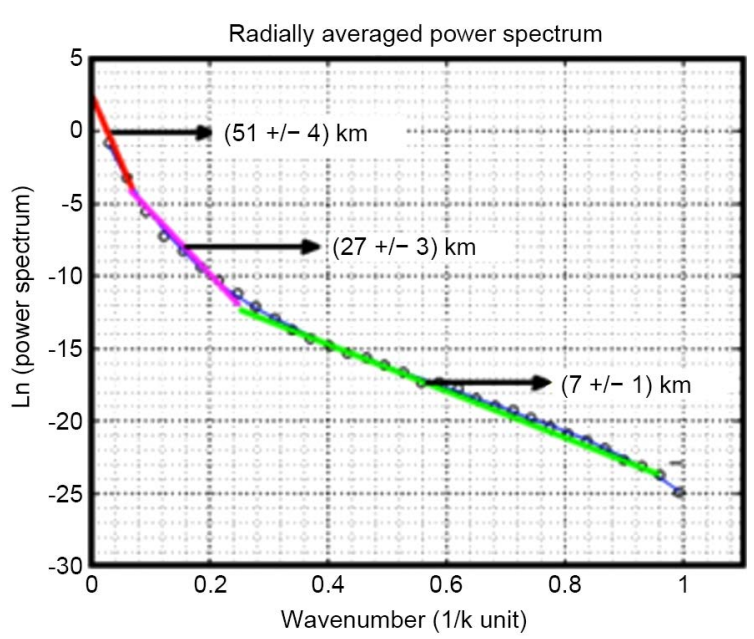

Figure 15. Power spectrum versus frequency for profile $\mathrm{P}_{4}$ (Fontem, Mamfe region).

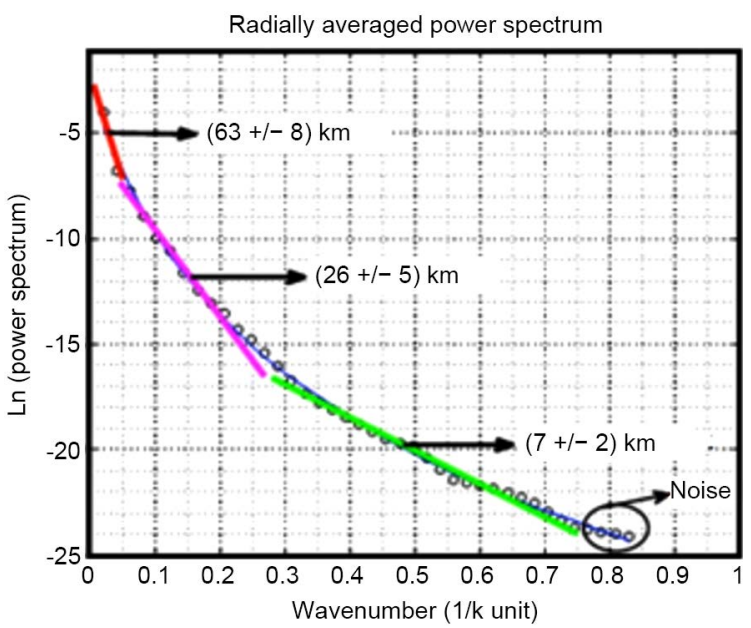

Figure 16. Power spectrum versus frequency for profile $\mathrm{P}_{5}$ (Bafoussam region).

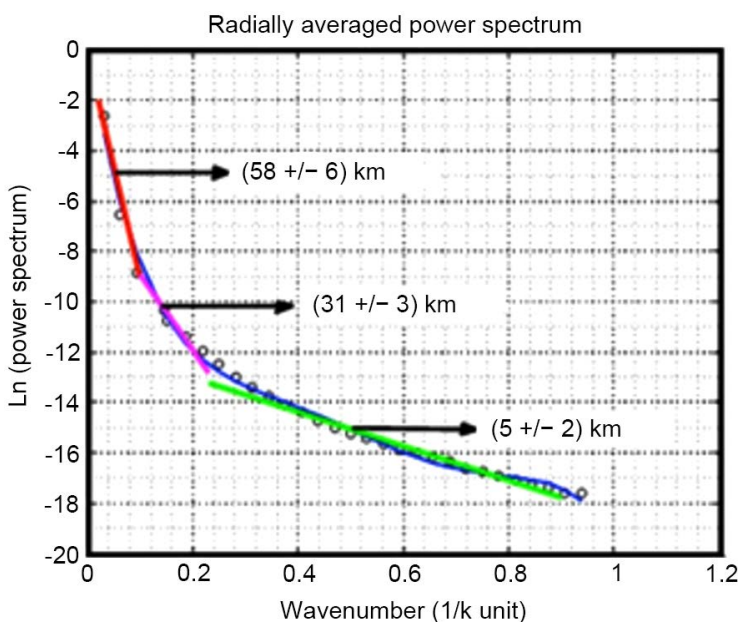

Figure 17. Power spectrum versus frequency for profile $\mathrm{P}_{6}$ (Kumbo region). 


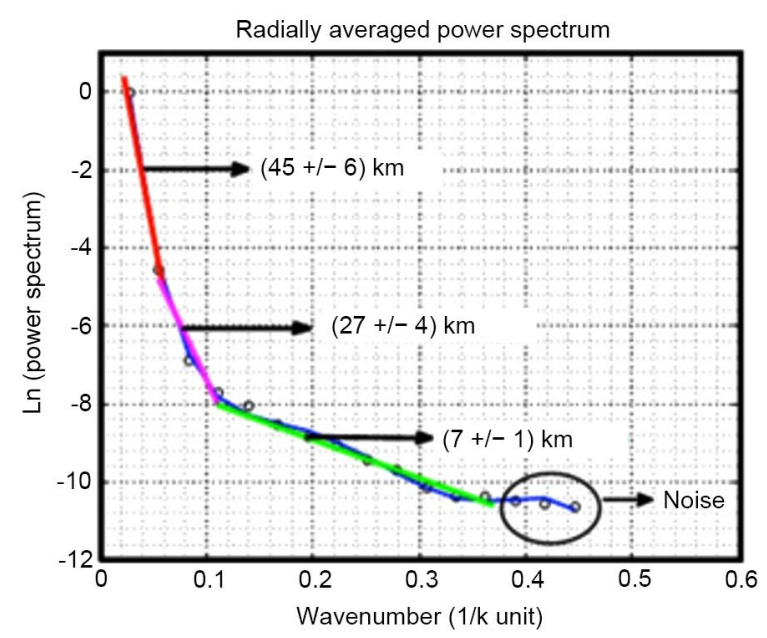

Figure 18. Power spectrum versus frequency for profile $\mathrm{P}_{7}$ (Ngambe region).

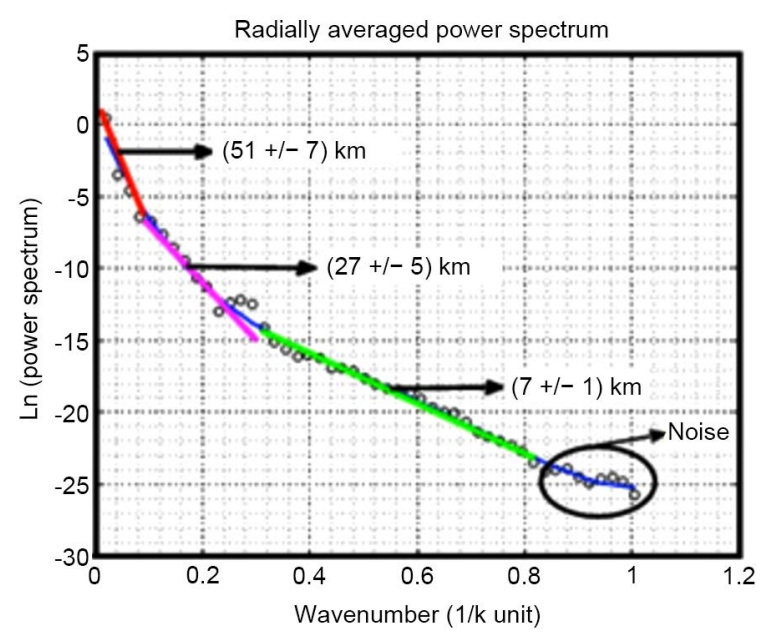

Figure 19. Power spectrum versus frequency for profile $\mathrm{P}_{8}$ (Eseka region).

Bouguer anomalies are negative, the crust has a normal thiskness. The results can also suggest the fact that neither the Kumbo region nor the Mt Cameroon area is isostatically compensated. Another fact is that the northern edge of the Congo craton that constitutes a boundary with the Pan-african belt presents a relatively thin crust.

\subsubsection{The Depth of Some Interesting Shallow Structures}

Some interesting shallow structures have been identified on the Bouguer and the third-order residual anomaly maps (Figure 6 and Figure 11). Based on the spectral analysis, the following depths have been obtained: (10 \pm 2) $\mathrm{km}$ in the Mt Cameroon region compared to $(7 \pm 2)$ and $(7 \pm 1) \mathrm{km}$ in Manyemen and Fontem respectively. In addition, $(5 \pm 2) \mathrm{km}$ is estimated for the locality of Kumbo and (7 \pm 2$) \mathrm{km}$ in Bafoussam. Finally, $(6 \pm 1) \mathrm{km}$ and (7 \pm 1$) \mathrm{km}$ were determined for Ngambe and Eseka regions respectively.

As mentioned before, the study area shows many dense and less dense intrusive structures due to volcanic activity, which may be related to the mineralization signs previously illustrated by [31]. Thus, the depths found in the present work predict many economic opportunities in the study area.

\section{Conclusion}

The present work shows new findings which prove the efficiency of the Earth Gravitational Model (EGM2008) 
in analyzing crustal structures beneath the south western Cameroon. It also shows that spectral analysis is an adequate technique to estimate the depths of either the Moho discontinuity using the Bouguer anomalies derived from EGM2008 or superficial discontinuities by the mean of the residual anomalies. The results obtained in the present work are in good agreement with many other findings of previous geophysical investigations. The EGM2008 geopotential field gravity model can be therefore used for further investigations in volcanic areas such as the oceanic part of the Cameroon Volcanic Line (CVL). These results illustrate a general thinning of the crust and also suggest that there is not isostatic compensation in the study area, especially in the Mount Cameroon and Kumbo regions. Furthermore, shallow structures with various densities are enlightened on residual anomaly map and can justify the scientific and socio-economic interests of the study area.

\section{References}

[1] Fairhead, J.D. and Okereke, C.S. (1987) A Regional Study of the West African Rift System in Nigeria and Cameroon and Its Tectonic Interpretation. Tectonophysics, 143, 141-159. http://dx.doi.org/10.1016/0040-1951(87)90084-9

[2] Poudjom-Djomani, Y.H., Boukeke, D.B., Legeley-Padovani, A., Nnange, J.M., Ateba-Bekoa, A.Y. and Fairhead, J.D. (1996) Levés gravimétriques de reconnaissance du Cameroun. ORSTOM, Paris.

[3] Poudjom-Djomani, Y.H. (1993) Apport de la Gravimétrie à l’étude de la Lithosphère continentale et implications géodynamiques. Etude d’un bombement intraplaque: Le massif de l'Adamaoua (Cameroun). Thèse de Doctorat Ph.D., Université de Paris-Sud, Centre d’Orsay. No. d’ordre 2798, Ed. ORSTOM, 229 p.

[4] Poudjom-Djomani, Y.H., Diament, M. and Wilson, M. (1997) Lithospheric Structure across the Adamawa Plateau (Cameroon) from Gravity Studies. Tectonophysics, 273, 317-327. http://dx.doi.org/10.1016/S0040-1951(96)00280-6

[5] Nnange, J.M., Ngako, V., Fairhead, J.D. and Ebinger, C.J. (2000) Depths to Density Discontinuities Beneath the Adamawa Plateau Region, Central Africa, from Spectral Analyses of New and Existing Gravity Data. Journal of African Earth Sciences, 30, 887-901. http://dx.doi.org/10.1016/S0899-5362(00)00058-0

[6] Noutchogwe, T.C. (2010) Investigation géophysique dans la région de l’Adamaoua par les méthodes gravimétriques et magnétiques: Implications structurales et Hydrogéologiques. Ph.D. Thesis, University of Yaounde I, Yaounde, 146 p.

[7] Marcel, J., Njandjock, N.P., Tabob, C.T. and Manguelle-Dicoum, E. (2010) Moho Depth Estimates for the Cameroon Volcanic Line from Gravity Data. International Journal of Economic and Environmental Geology, 1, 17-20.

[8] Pavlis, N.K., Holmes, S.A., Kenyon, S.C. and Factor, J.K. (2008) An Earth Gravitational Model to Degree 2160: EGM2008. Presented at the EGU General Assembly, Vienna Austria, April, 13-18.

[9] Kiamehr, R. and Gomez-Ortiz, D. (2009) A New 3D Moho Depth Model for Iran Based on the Terrestrial Gravity Data and EGM2008 Model. Geophysical Research Abstracts, 11, 3211.

[10] Gruber, T. (2009) Evaluation of the EGM2008 Gravity Field by Means of GPS-Levelling and Sea Surface Topography Solutions. Institute of Astronomical and Physical Geodesy Technical Univ. Munich, Germ. www.fesg.bv.tum.de/.../200904 Newton Bulletin Re

[11] Arabelos, D.N. and Tscherning, C.C. (2010) A Comparison of Recent Earth Gravitational Models with Emphasis on Their Contribution in Refining the Gravity and Geoid at Continental or Regional Scale. Journal of Geodesy, 84, 643660. http://dx.doi.org/10.1007/s00190-010-0397-z

[12] Eyike, A., Werner, S.C., Ebbing, J. and Manguelle-Dicoum, E. (2010) On the Use of Global Potential Field Models for Regional Interpretation of the West and Central African Rift System. Tectonophysics, 492, 25-39. http://dx.doi.org/10.1016/j.tecto.2010.04.026

[13] Ngatchou, H.E., Liu, G., Tabod, C.T., Wang, Y., Kamguia, J., Nguiya, S., Tiedeu, A. and Ke, X. (2014) Crustal Structure beneath Cameroon from EGM2008. Geodesy and Geodynamics, 5, 1-7. http://dx.doi.org/10.3724/SP.J.1246.2014.01001

[14] Déruelle, B., Moreau, C., Nkoumbou, C., Kambou, R., Lissom, J., Njonfang, E., Ghogomu, R.T. and Nono, A. (1991) The Cameroun Line: A Review. In: Kampunzu, A.B. and Lubala, R.T., Eds., Magmatism in Extensional Structural Settings, Springer-Verlag, Heidelberg, 274-328. http://dx.doi.org/10.1007/978-3-642-73966-8_12

[15] Fitton, J.G. (1987) The Cameroon Line, West Africa: A Comparison between Oceanic and Continental Alkaline Volcanism. Alkali Igneous Rocks. Geological Society London Special Publications, 30, 273-291. http://dx.doi.org/10.1144/GSL.SP.1987.030.01.13

[16] Déruelle, B., Ngounouno, I. and Demaiffe, D. (2007) The Cameroon Hot Line (CHL): A Unique Example of Active Alkaline Intraplate Structure in Both Oceanic and Continental Lithospheres. Comptes Rendus Geoscience, 339, 589600. http://dx.doi.org/10.1016/j.crte.2007.07.007

[17] Hedberg, J.D. (1968) A Geological Analysis of the Cameroon Trend. PhD Thesis, University of Princeton, Princeton. 
[18] Nkoumbou, C., Deruelle, B. and Velde, D. (1995) Petrology of Mt. Etinde Nephelinite Series. Journal of Petrology, 36, 373-395. http://dx.doi.org/10.1093/petrology/36.2.373

[19] Fitton, J.G. and Dunlop, H.M. (1985) The Cameroon Line, West Africa, and Its Bearing on the Origin of Oceanic and Continental Alkali Basalt. Earth and Planetary Science Letters, 72, 23-38. http://dx.doi.org/10.1016/0012-821X(85)90114-1

[20] Meyers, J.B. and Rosendahl B.R. (1991) Seismic Reflection Character of the CVL: Evidence for Uplifted Oceanic Crust. Geology, 19, 1072-1076. http://dx.doi.org/10.1130/0091-7613(1991)019<1072:SRCOTC>2.3.CO;2

[21] Princivalle, F., Salviulo, G., Marzoli, A. and Piccirillo, E.M. (2000) Clinopyroxene of Spinel-Peridotite Mantle Xenoliths from Lake Nji (Cameroon Volcanic Line, W Africa): Crystal Chemistry and Petrological Implications, Contributions to Mineralogy and Petrology, 139, 503-508. http://dx.doi.org/10.1007/s004100000151

[22] Koch, P. (1953) Carte géologique de reconnaissance à l’échelle du 1/500 000 ${ }^{\text {ème }}$ : Levés effectués de $1949-1950$ avec notice explicative sur la feuille Banyo. Publication de la Direction des Mines et de la Géologie du Cameroun, Imprimerie Nationale, Yaoundé Cameroun.

[23] Champetier de Ribes, G. and Aubague M. (1956) Carte géologique de reconnaissance au 1/500000 ${ }^{\text {ème }}$. Publication de la Direction des Mines et de la Géologie du Cameroun, Imprimerie de Rébon, Paris, France.

[24] Weecksteen, G. (1957) Carte géologique de reconnaissance à l'échelle du 1/500 000 ème, feuille Douala-Est, avec notice explicative. Publication de la Direction des Mines et de la Géologie du Cameroun.

[25] Champetier de Ribes, G. and Reyre, D. (1959) Carte géologique de reconnaissance du Cameroun au 1/500000 ${ }^{\text {ème }}$. Feuille Yaoundé-Ouest, avec notice explicative. Imprimerie de Rébon, Paris, France, 31 p.

[26] Dumort, J.C. (1968) Carte géologique de reconnaissance de Douala Ouest à 1/500 $000^{\text {ème }}$. Publication de la Direction des Mines et de la Géologie du Cameroun, Imprimerie Nationale, Yaoundé Cameroun.

[27] Peronne, Y. (1969) Carte géologique de reconnaissance de Wum-Banyo à 1/500 000 ème . Publication de la Direction des Mines et de la Géologie du Cameroun.

[28] Maurizot, P., Abessolo, A., Feybesse, J.L. and Johan Lecomte, P. (1986) Etude de prospection minière du Sud-Ouest Cameroun. Synthèse des travaux de 1978 à 1985. Rapp. BRGM 85, CMR 066.

[29] Kling, G.W., Evans, W.C., Tanyileke, G., Kusakabe, M., Ohba, T., Yoshida, Y., Hell, J.V. and Carpenter, S.R. (2005) Degassing Lakes Nyos and Monoun: Defusing Certain Disaster. Proceedings of the National Academy of Sciences of the United States of America, 102, 14185-14190. http://dx.doi.org/10.1073/pnas.0502274102

[30] Lucie, M. (2010) The Structure of Guadeloupe, Maderas and Mt Cameroon Volcanoes and the Impact of Strike-Slip Movements. Applied Geology, Universite Blaise Pascal-Clermont-Ferrand II, Trinity College Dublin, Dublin.

[31] Ntep, G.P. (2001) Carte thématique des ressources minerals du Cameroun sur fond géologique. Ministère des Mines, de l'Eau et de l'Energie, Publié par CAPAM.

[32] Nkouathio, D.G., Kagou Dongmo, A., Bardintzeff, J.M., Wandji, P., Bellon, H. and Pouclet, A. (2008) Evolution of Volcanism in Graben and Horst Structures along the Cenozoic Cameroon Line (Africa): Implications for Tectonic Evolution and Mantle Source Composition. Mineralogy and Petrology, 94, 287-303. http://dx.doi.org/10.1007/s00710-008-0018-1

[33] Pavlis, N.K., Holmes, S.A., Kenyon, S.C. and Factor, J.K. (2012) The Development and Evaluation of the Earth Gravitational Model 2008 (EGM2008). Journal of Geophysical Research, 17, Article ID: B04406. http://dx.doi.org/10.1029/2011jb008916

[34] Amante, C. and Eakins, B.W. (2009) ETOPO1 1 Arc Minute Global Relief Model: Procedures, Data Sources and Analysis. NOAA Technical Memorandum NESDIS NGDC-24.

[35] Schoeffler, J. (1975) Gravimétrie appliquée aux recherches structurales et à la prospection pétrolière et minière. Edit. Technip. 27 Rue Ginoux, Paris, 288 p.

[36] Vanié, L.T.A., Khattach, D. and Houari, M.R. (2005) Apport des filtrages des anomalies gravimétriques à l’étude des structures profondes du Maroc oriental. Bulletin de l'Institut Scientifique, Section Sciences de la Terre, 29-40.

[37] Zeng, H. (1989) Estimation of the Degree of Polynomial Fitted to Gravity Anomalies and Its Applications. Geophysical Prospecting, 37, 959-973. http://dx.doi.org/10.1111/j.1365-2478.1989.tb02242.x

[38] Jacobsen, B.H. (1987) A Case for Upward Continuation as a Standard Separation Filter for Potential-Field Maps. Geophysics, 52, 390-398. http://dx.doi.org/10.1190/1.1442378

[39] Blakely, R.J. (1996) Potential Theory in Gravity and Magnetic Applications. Cambridge University Press, Cambridge, $441 \mathrm{p}$.

[40] Blakely, R.J. and Simpson, R.W. (1986) Approximating Edges of Source Bodies from Magnetic or Gravity Anomalies. Geophysics, 51, 1494-1498. http://dx.doi.org/10.1190/1.1442197 
[41] Agocs, W.B. (1951) Least-Squares Residual Anomaly Determination. Geophysics, 16, 686-696. http://dx.doi.org/10.1190/1.1437720

[42] Baranov, V. (1954) Sur une nouvelle method de calcul de l'anomalie régionale. Geophysical Prospecting, 2, $203-226$. http://dx.doi.org/10.1111/j.1365-2478.1954.tb01287.x

[43] Grant, F. (1954) A Theory for the Regional Correction of Potential Field Data. Geophysics, 19, 23-45. http://dx.doi.org/10.1190/1.1437968

[44] Abdelrahman, E.M., Riad, S., Refai, E. and Amin, Y. (1985) On the Least-Squares Residual Anomaly Determination. Geophysics, 50, 473-480. http://dx.doi.org/10.1190/1.1441925

[45] Abdelrahman, E.M., Bayoumi, A.I., Abdelhady, Y.E., Gobashi, M.M. and El-Araby, H.M. (1989) Gravity Interpretation Using Correlation Factors between Successive Least Squares Residual Anomalies. Geophysics, 54, 1614-1621. http://dx.doi.org/10.1190/1.1442629

[46] Njandjock Nouck, P., Oyoa, V., Ndougsa, M.T. and Bisso, D. (2012) C++ Code for Separation of Regional and Residual Anomaly of Potential Field. Greener Journal of Physical Sciences, 2, 120-130.

[47] Spector, A. and Grant, F.S. (1970) Statistical Models for Interpreting Aeromagnetic Data. Geophysics, 35, $293-302$. http://dx.doi.org/10.1190/1.1440092

[48] Gérard, A. and Debeglia, N. (1975) Automatic Three-Dimensional Modeling for the Interpretation of Gravity or Magnetic Anomalies. Geophysics, 40, 1014-1034. http://dx.doi.org/10.1190/1.1440578

[49] Bhattacharyya, B.K. and Leu, L.K. (1977) Spectral Analysis of Gravity and Magnetic Anomalies Due to Rectangular Prismatic Bodies. Geophysics, 42, 41-50. http://dx.doi.org/10.1190/1.1440712

[50] Bhattacharyya, B.K. (1978) Computer Modeling in Gravity and Magnetic Interpretation. Geophysics, 43, 912-929. http://dx.doi.org/10.1190/1.1440873

[51] Spector, A. and Parker, W. (1979) Computer Compilation and Interpretation of Geophysical Data in Geophysics and Geochemistry in the Search for Metallic Ores. Edited by Hood, J.P., Geological Survey of Canada, 527-544.

[52] Ponsard, J.F. (1984) La marge du craton Ouest africain du Sénégal à la Sierra Léone: Interprétation géophysique de la chaîne Pan africaine et des bassins du Protérozoïque à l'actuel. Univ. Paris, France, 6.

[53] Bansal, A.R. and Dimri, V.P. (2001) Depth Estimation from the Scaling Power Spectral Density of Non-Stationary Gravity Profile. Pure and Applied Geophysics, 158, 799-812. http://dx.doi.org/10.1007/PL00001204

[54] Gomez-Ortiz D., Tejero-Lopez R., Babin-Vich R. and Rivas-Ponce A. (2005) Crustal Density Structure in the Spanish Central System Derived from Gravity Data Analysis (Central Spain). Tectonophysics, 403, 131-149. http://dx.doi.org/10.1016/j.tecto.2005.04.006

[55] Njandjock Nouck, P., Manguelle-Dicoum, E., Ndougsa, M.T. and Tabod, C.T. (2006) Spectral Analysis and Gravity Modelling in the Yagoua, Cameroon, Sedimentary Basin. Geofísica internacional, 45, 209-215.

[56] Kivior, I. and Boyd, D. (1998) Interpretation of Aeromagnetic Experimental Survey in the Eromanga/Cooper Basin. Canadian Journal of Exploration Geophysics, 34, 58-66.

[57] Tokam, A.P., Tabod, C.T., Nyblade, A.A., Jordi, J., Wiens, D.A. and Pasyanos, M.E. (2010) Structure of the Crust Beneath Cameroon, West Africa, from the Joint Inversion of Rayleigh Wave Group Velocities and Receiver Functions. Geophysical Journal International, 183, 1061-1076. http://dx.doi.org/10.1111/j.1365-246X.2010.04776.x

[58] Tabod, C.T. (1991) Seismological Studies of the Cameroon Volcanic Line, in West Africa. PhD Thesis, University of Leeds, Leeds.

[59] Tadjou, J.M., Nouayou, R., Kamguia, J., Kande, H.L. and Manguelle-Dicoum, E. (2009) Gravity Analysis of the Boundary between the Congo Craton and the Pan-African Belt of Cameroon. Austrian Journal of Earth Sciences, 102, 71-79. 


\section{Submit or recommend next manuscript to SCIRP and we will provide best service for you:}

Accepting pre-submission inquiries through Email, Facebook, LinkedIn, Twitter, etc.

A wide selection of journals (inclusive of 9 subjects, more than 200 journals)

Providing 24-hour high-quality service

User-friendly online submission system

Fair and swift peer-review system

Efficient typesetting and proofreading procedure

Display of the result of downloads and visits, as well as the number of cited articles

Maximum dissemination of your research work

Submit your manuscript at: http://papersubmission.scirp.org/ 